\title{
Nonlinear Fracture of Functionally Graded Beams under Mode II Loading Conditions
}

\section{I. Rizov}

Department of Technical Mechanics, University of Architecture, Civil Engineering and Geodesy, Sofia, Bulgaria

V_RIZOV_FHE@UACG.BG

УДК 539.4

\section{Нелинейное разрушение функционально-градиентных балок при нагру- жении по моде II}

\section{В. И. Ризов}

Университет архитектуры, гражданского строительства и геодезии, София, Болгария

Теоретически изучено разрушение функичинально-градиентных балок по моде II. Предложена конфигурачия балки с двумя симметричными продольными трещинами для условий нагружения по моде II. Механическое поведение балки описано с помощью нелинейного соотношения между напряжением и деформаџией. Процесс разрушения проанализирован на основе применения Ј-интеграла. Получено аналитическое решение на основе Ј-интеграла для двух законов изменения модуля упругости по высоте балки. Выполнен нелинейный анализ скорости высвобождения энергии деформаџии с учетом баланса энергии для проверки решений на основе Ј-интеграла. Полученные результаты могут быть использованы для оптимизации функционально-градиентной структуры балки при разрушении по моде II. Аналитические решения удобны также для параметрического изучения нелинейного разрушения функиионально-градиентных балок, что дает возможность в дальнейшем развивать нелинейную механику разрушения функиионально-градиентных материалов.

Ключевые слова: функционально-градиентная балка, нелинейность материала, трещиностойкость по моде II, аналитическое решение.

Introduction. The basic idea of functionally graded materials is that by continuous variation of the composition of their constituents along one or more coordinates, optimum performance of structural members can be achieved to external loading [1-12]. The advance in functionally graded materials technologies is closely related with investigations of fracture behavior of these novel materials [13-18].

A longitudinal crack in a strip of a functionally graded material under edge loading consisting of axial forces and bending moments has been studied by applying linear-elastic fracture mechanics [15]. Analytical solutions have been derived for stress intensity factors.

Various studies of fracture in functionally graded materials have been reviewed in [16]. Cracks oriented both parallel and perpendicular to the gradient direction have been analyzed assuming linear-elastic behavior. Influence has been investigated of material properties on the stress intensity factors.

Cracks in structures composed by functionally graded materials have been studied by applying linear-elastic fracture mechanics [17]. A method for predicting the strength of structural members corresponding to brittle crack propagation has been developed. The method has been applied to plates loaded in tension and beams under three-point bending. 
Fracture behavior of functionally graded linear-elastic beams in three-point bending has been analyzed by using the compliance approach [18]. An equivalent beam of variable height has been suggested. Different laws for variation of the modulus of elasticity along the beam span have been considered in the fracture analysis. A solution for Mode I stress intensity factor has been derived by using the compliance approach.

It can be summarized that fracture in functionally graded beams has been studied intensively for the last two decades. The present paper contributes towards this topic by conducting a nonlinear fracture analysis of functionally graded beams under Mode II loading conditions.

Mode II Fracture Analysis. The fracture problem considered in the present paper is illustrated in Fig. 1. There are two longitudinal cracks of length a located symmetrically with respect to the beam centroid (it should be mentioned that the present paper was motivated mainly by the fact that functionally graded materials can be built up layer by layer [8] which is a premise for appearance of longitudinal cracks between layers). The material is functionally graded along the beam height symmetrically with respect to the centroid. The beam has a rectangular cross-section of width $b$ and height $h$. The internal crack arm thickness is $2 h_{2}$. The beam is clamped in the right-hand end. The loading consists of a tensile force $F$ applied centrically at the free end of the internal crack arm (in this way, Mode II crack loading conditions are generated). Obviously, the lower and the upper crack arms are free of stresses.
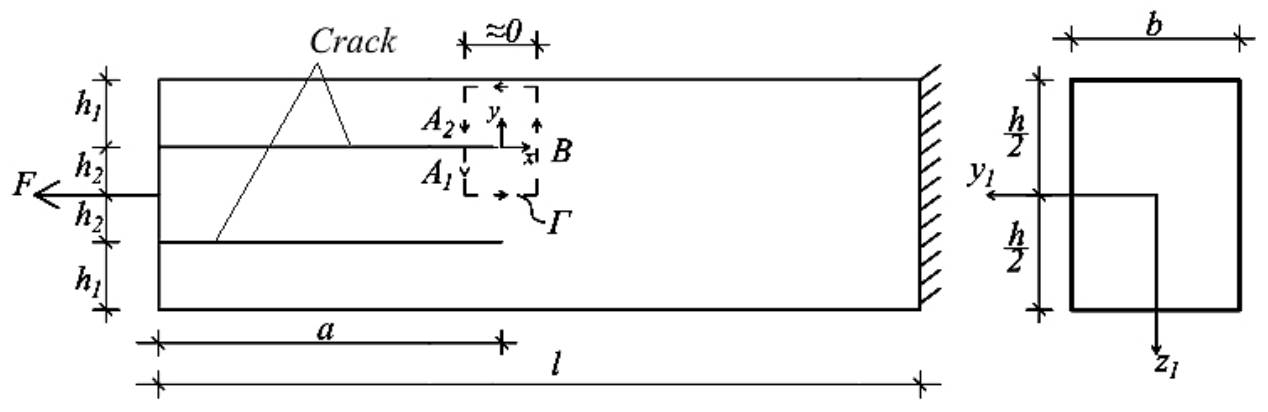

Fig. 1. Functionally graded beam with two symmetric cracks.

The fracture was studied theoretically by applying the $J$-integral approach. For functionally graded materials, the $J$-integral was formulated as [19]

$$
J=\int_{\Gamma}\left[u_{0} \cos \alpha-\left(p_{x} \frac{\partial u}{\partial x}+p_{y} \frac{\partial v}{\partial x}\right)\right] d s-\int_{A} \frac{\partial u_{0}}{\partial x} q d A,
$$

where $\Gamma$ is a contour of integration going from the lower crack face to the upper crack face in the counter clockwise direction, $u_{0}$ is the strain energy density, $\alpha$ is the angle between the outwards normal vector to the contour of integration and the crack direction, $p_{x}$ and $p_{y}$ are the components of the stress vector, $u$ and $v$ are the components of the displacement vector with respect to the crack tip coordinate system $x y$ ( $x$ is directed along the crack), $d s$ is a differential element along the contour, $A$ is the area enclosed by that contour, and $q$ is a weight function with a value of unity at the crack tip, zero along the contour and arbitrary elsewhere. It should be specified that the partial derivative, $\partial u_{0} / \partial x$, exists only if the material property is an explicit function of $x$ [19].

The beam configuration considered is symmetric with respect to the centroid (Fig. 1). Therefore, only the upper half of the beam, $-h / 2 \leq z_{1} \leq 0$, was analyzed. The integration 
was performed along the contour, $\Gamma$, that consists of the beam cross-sections ahead and behind the crack tip (Fig. 1). It was mentioned above that the upper crack arm is stress free. Therefore, the $J$-integral value in the upper crack arm is zero. The $J$-integral solution was written as

$$
J=2\left(J_{A_{1}}+J_{B}\right)
$$

where $J_{A_{1}}$ and $J_{B}$ are the $J$-integral values in segments $A_{1}$ and $B$, respectively (segment $A_{1}$ coincides with the upper half of the cross-section of the internal crack arm, segment $B$ coincides with the upper half of the beam cross-section ahead of the crack tip). The expression in the brackets in Eq. (2) is doubled since there are two symmetric cracks in the beam (Fig. 1).

The modulus of elasticity, $E$, varies continuously along the beam height according to the following power-law:

$$
E\left(z_{1}\right)=E_{0}+\frac{E_{1}-E_{0}}{(h / 2)^{2 k}} z_{1}^{2 k}, \quad k=1,2, \ldots, n,
$$

where $E_{0}$ and $E_{1}$ are the values of $E$ in the beam cross-section centre and in the beam edge, respectively. Here, $k$ is a parameter that dictates the material property variation profile in the $z_{1}$-axis direction (along the beam height). By using different values of $k$, one can model various distributions of $E$ along the beam height.

The mechanical response of the functionally graded beam (Fig. 1) was described by the following nonlinear stress-strain relation [20]:

$$
\sigma=\frac{E \varepsilon}{\sqrt{1+\left(\frac{\varepsilon}{t}\right)^{2}}},
$$

where $\sigma$ is the stress, $\varepsilon$ is the strain, $E$ is expressed by the power-law relation (3), and $t$ is a material property (usually, $t$ is equal to unit [20]). The stress-strain curve is shown schematically in Fig. 2.

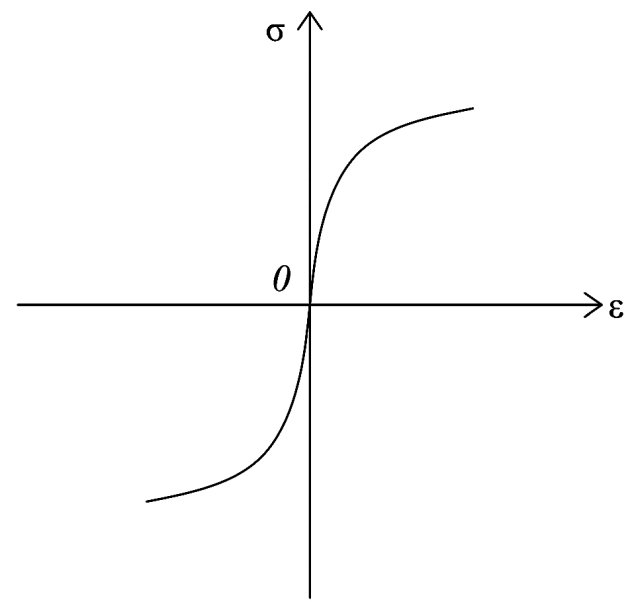

Fig. 2. Nonlinear stress-strain curve. 
It should be noted that the present nonlinear fracture analysis holds for nonlinear elastic material behavior. However, the analysis is applicable also for elastic-plastic behavior, if the external load magnitude increases only, i.e., if the functionally graded beam considered undergoes active deformation [21].

First, the integration was performed in segment $A_{1}$ of the integration contour (Fig. 1). The $J$-integral components were written as

$$
p_{x}=-\sigma, \quad p_{y}=0, \quad d s=d z_{1}, \quad \cos \alpha=-1,
$$

where the $z_{1}$-coordinate varies in the interval $\left[-h_{2}, 0\right]$. The stress, $\sigma$, was calculated by (4).

The following equation for equilibrium was used to derive the longitudinal strain, $\varepsilon_{c}$, in the internal crack arm behind the crack tip:

$$
\frac{F}{2}=\int_{-h_{2}}^{0} \sigma b d z_{1}
$$

From (3), (4), and (6), we obtained

$$
\varepsilon_{c}=\frac{t \eta}{\sqrt{t^{2}-\eta^{2}}}
$$

where

$$
\eta=\frac{F h^{2 k}(2 k+1)}{2 b\left[E_{0} h_{2} h^{2 k}(2 k+1)-2^{2 k}\left(-h_{2}\right)^{2 k+1}\left(E_{1}-E_{0}\right)\right]} .
$$

The strain energy density is equal to the area, $O P Q$, enclosed by the stress-strain curve [21] (refer to Fig. 3):

$$
u_{0}=\int_{0}^{\varepsilon} \sigma d \varepsilon
$$

From Eqs. (4) and (8), we derived

$$
u_{0}=E t^{2}\left[\sqrt{1+\left(\frac{\varepsilon}{t}\right)^{2}}-1\right] .
$$

The following equation from mechanics of materials was applied to determine the partial derivative, $\partial u / \partial x$, in (1):

$$
\frac{\partial u}{\partial x}=\varepsilon_{c}
$$

The partial derivative, $\partial u_{0} / \partial x$, in the second integral in (1) was written as

$$
\frac{\partial u_{0}}{\partial x}=0,
$$

since the strain energy density does not depend explicitly on $x$ (the modulus of elasticity is not a function of $x$, because the material is functionally graded along to the beam height only [refer to (3)]. 


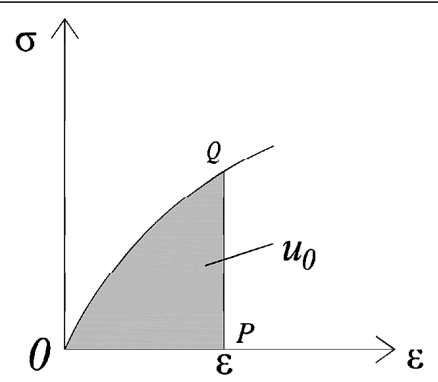

Fig. 3. Strain energy density.

By combining of (1), (3), (4), (5), (7), (8), (10), and (11), we derived

$$
J_{A_{1}}=t^{2}\left[1-\left(\sqrt{1+\left(\frac{\varepsilon_{c}}{t}\right)^{2}}\right)^{-1}\right]\left(E_{0} h_{2}-\frac{E_{1}-E_{0}}{h^{2 k}} \frac{2^{2 k}\left(-h_{2}\right)^{2 k+1}}{2 k+1}\right) .
$$

The integration in segment $B$ of the integration contour (Fig. 1) was performed in the following way. The $J$-integral components were written as

$$
p_{x}=\sigma, \quad p_{y}=0, \quad d s=-d z_{1}, \quad \cos \alpha=1,
$$

where $z_{1}$ varies in the interval $[0,-h / 2]$. The stress, $\sigma$, was expressed by Eq. (4).

The following equilibrium equation was applied to determine the longitudinal strain, $\varepsilon_{d}$, in the uncracked beam portion, $x \geq 0$ :

$$
\frac{F}{2}=\int_{-h / 2}^{0} \sigma b d z_{1}
$$

From (3), (4), and (14), we found

$$
\varepsilon_{d}=\frac{t \vartheta}{\sqrt{t^{2}-\vartheta^{2}}}
$$

where

$$
\vartheta=\frac{F(2 k+1)}{b h\left(2 k E_{0}+E_{1}\right)}
$$

The partial derivative, $\partial u / \partial x$, was written as

$$
\frac{\partial u}{\partial x}=\varepsilon_{d}
$$

By combining of (1), (3), (4), (9), (11), (13), and (16), we derived

$$
J_{B}=t^{2}\left[\left(\sqrt{1+\left(\frac{\varepsilon_{d}}{t}\right)^{2}}\right)^{-1}-1\right] \frac{h}{2} \frac{2 k E_{0}+E_{1}}{2 k+1} .
$$


The $J$-integral final solution was obtained by combining of (2), (12), and (17)

$$
\begin{gathered}
J=2 t^{2}\left[1-\left(\sqrt{1+\left(\frac{\varepsilon_{c}}{t}\right)^{2}}\right)^{-1}\right]\left(E_{0} h_{2}-\frac{E_{1}-E_{0}}{h^{2 k}} \frac{2^{2 k}\left(-h_{2}\right)^{2 k+1}}{2 k+1}\right)- \\
-t^{2}\left[\left(\sqrt{1+\left(\frac{\varepsilon_{d}}{t}\right)^{2}}\right)^{-1}-1\right] h \frac{2 k E_{0}+E_{1}}{2 k+1} .
\end{gathered}
$$

The $J$-integral nonlinear solution (18) was verified by performing an analysis of the strain energy release rate with taking into account the material nonlinearity. Only the beam upper half was considered due to the symmetry (Fig. 1). A small increase, $\delta a$, was given to each of the two cracks. The external force magnitude was constant. Thus, the work of the external force was written as

$$
\delta W=F_{h} \delta u_{F},
$$

where $\delta u_{F}$ is the increases of the displacement of the force application point due to the crack increase [here, $F_{h}=0.5 F$, because only the upper half of the beam was considered in the analysis due to the symmetry (Fig. 1)]. The increase of the strain energy, $\delta U$, was expressed as

$$
\delta U=\frac{\partial U}{\partial a} \delta a
$$

The increase of the strain energy release rate was written as

$$
\delta G=G b \delta a
$$

The energy balance was expressed as

$$
\delta W=\delta U+\delta G
$$

From Eqs. (19)-(22), we derived

$$
G=\frac{F_{h}}{b} \frac{\partial u_{F}}{\partial a}-\frac{1}{b} \frac{\partial U}{\partial a} .
$$

The displacement, $u_{F}$, was determined by the Castigliano's theorem for structures exhibiting material nonlinearity:

$$
u_{F}=\frac{\partial U^{*}}{\partial F_{h}},
$$

where $U^{*}$ is the beam complimentary strain energy, which was written as (Fig. 1)

$$
U^{*}=\int_{-h_{2}}^{0} u_{0}^{*} b a d z_{1}+\int_{-h / 2}^{0} u_{0}^{*} b(l-a) d z_{1} .
$$


The complimentary stain energy density, $u_{0}^{*}$, in Eq. (25) is equal to the area that supplements the area $O P Q$ to a rectangle (Fig. 3). Therefore, $u_{0}^{*}$ was written as

$$
u_{0}^{*}=\sigma \varepsilon-u_{0} .
$$

By combining of Eqs. (3), (10), and (26), we obtained

$$
u_{0}^{*}=E t^{2}\left[1-\left(\sqrt{1+\left(\frac{\varepsilon}{t}\right)^{2}}\right)^{-1}\right] .
$$

From Eqs. (3), (7), (15), (25), and (27), we found

$$
\begin{aligned}
U^{*}= & a b t^{2}\left[1-\left(\sqrt{1+\left(\frac{\varepsilon_{c}}{t}\right)^{2}}\right)^{-1}\right]\left(E_{0} h_{2}-\frac{E_{1}-E_{0}}{h^{2 k}} \frac{2^{2 k}\left(-h_{2}\right)^{2 k+1}}{2 k+1}\right)+ \\
& +b(l-a) t^{2}\left[1-\left(\sqrt{1+\left(\frac{\varepsilon_{d}}{t}\right)^{2}}\right)^{-1}\right] \frac{h}{2} \frac{2 k E_{0}+E_{1}}{2 k+1} .
\end{aligned}
$$

The strain energy, $U$, was written as (Fig. 1)

$$
U=\int_{-h_{2}}^{0} u_{0} b a d z_{1}+\int_{-h / 2}^{0} u_{0} b(l-a) d z_{1} .
$$

From Eqs. (3), (7), (9), (15), and (29), we obtained

$$
\begin{gathered}
U=a b t^{2}\left[\sqrt{1+\left(\frac{\varepsilon_{c}}{t}\right)^{2}}-1\right]\left(E_{0} h_{2}-\frac{E_{1}-E_{0}}{h^{2 k}} \frac{2^{2 k}\left(-h_{2}\right)^{2 k+1}}{2 k+1}\right)+ \\
+b(l-a) t^{2}\left[\sqrt{1+\left(\frac{\varepsilon_{d}}{t}\right)^{2}}-1\right] \frac{h}{2} \frac{2 k E_{0}+E_{1}}{2 k+1}
\end{gathered}
$$

After combining of Eqs. (9), (15), (23), (24), (28), and (30) and performing the necessary mathematical operations, we derived

$$
\begin{aligned}
G=2 t^{2}[1 & \left.-\left(\sqrt{1+\left(\frac{\varepsilon_{c}}{t}\right)^{2}}\right)^{-1}\right]\left(E_{0} h_{2}-\frac{E_{1}-E_{0}}{h^{2 k}} \frac{2^{2 k}\left(-h_{2}\right)^{2 k+1}}{2 k+1}\right)- \\
& -t^{2}\left[\left(\sqrt{1+\left(\frac{\varepsilon_{d}}{t}\right)^{2}}\right)^{-1}-1\right] h \frac{2 k E_{0}+E_{1}}{2 k+1} .
\end{aligned}
$$


Equation (31) is exact match of Eq. (18), which is a verification of the nonlinear fracture analysis developed in the present paper.

The Mode II fracture behavior of the functionally graded beam in Fig. 1 was investigated also assuming that the modulus of elasticity varies along the beam height according to the following exponential law:

$$
E\left(z_{1}\right)=E_{0} e^{-\lambda z_{1}}, \quad \lambda>0 \quad \text { at } \quad-h / 2 \leq z_{1} \leq 0,
$$

where $E_{0}$ is the modulus of elasticity in the beam cross-section centre and $\lambda$ is a material property.

The beam mechanical behavior was described by Eq. (3).

The $J$-integral components in segment $A_{1}$ of the integration contour (Fig. 1) were obtained by (5).

The equilibrium equation (6) was used to determine $\varepsilon_{c}$. By combining of (4), (6), and (32), we derived

$$
\varepsilon_{c}=\frac{t \beta}{\sqrt{t^{2}-\beta^{2}}},
$$

where

$$
\beta=\frac{F \lambda}{2 b E_{0}\left(e^{\lambda h_{2}}-1\right)} .
$$

From (1), (4), (5), (9), (10), (11), (32), and (33), we obtained

$$
J_{A_{1}}=t^{2}\left[1-\left(\sqrt{1+\left(\frac{\varepsilon_{c}}{t}\right)^{2}}\right)^{-1}\right] \frac{E_{0}}{\lambda}\left(e^{\lambda h_{2}}-1\right) .
$$

The $J$-integral components in segment $B$ (Fig. 1) were expressed by (13). obtained

Equation (14) was used to obtain $\varepsilon_{d}$. By combining of (4), (14), and (32), we

$$
\varepsilon_{d}=\frac{t \rho}{\sqrt{t^{2}-\rho^{2}}},
$$

where

$$
\rho=\frac{F \lambda}{2 b E_{0}\left(e^{\lambda h / 2}-1\right)} .
$$

From (1), (4), (9), (11), (13), and (32), we derived

$$
J_{B}=t^{2}\left[\left(\sqrt{1+\left(\frac{\varepsilon_{d}}{t}\right)^{2}}\right)^{-1}-1\right] \frac{E_{0}}{\lambda}\left(e^{\lambda h / 2}-1\right) .
$$

Finally, (34) and (36) were substituted in (2):

$$
J=2 t^{2}\left[1-\left(\sqrt{1+\left(\frac{\varepsilon_{c}}{t}\right)^{2}}\right)^{-1}\right] \frac{E_{0}}{\lambda}\left(e^{\lambda h_{2}}-1\right)+
$$




$$
+2 t^{2}\left[\left(\sqrt{1+\left(\frac{\varepsilon_{d}}{t}\right)^{2}}\right)^{-1}-1\right] \frac{E_{0}}{\lambda}\left(e^{\lambda h / 2}-1\right) .
$$

In order to verify Eq. (37), a nonlinear analysis was developed of the strain energy release rate by using Eq. (23). The beam complimentary strain energy was found by Eq. (25). For this purpose, (4), (9), (25), (26), and (32) were combined:

$$
\begin{gathered}
U^{*}=a b t^{2}\left[1-\left(\sqrt{1+\left(\frac{\varepsilon_{c}}{t}\right)^{2}}\right)^{-1}\right] \frac{E_{0}}{\lambda}\left(e^{\lambda h_{2}}-1\right)+ \\
+b(l-a) t^{2}\left[1-\left(\sqrt{1+\left(\frac{\varepsilon_{d}}{t}\right)^{2}}\right)^{-1}\right] \frac{E_{0}}{\lambda}\left(e^{\lambda h / 2}-1\right) .
\end{gathered}
$$

The beam strain energy was obtained by combining of (9), (29), and (32):

$U=a b t^{2}\left[\sqrt{1+\left(\frac{\varepsilon_{c}}{t}\right)^{2}}-1\right] \frac{E_{0}}{\lambda}\left(e^{\lambda h_{2}}-1\right)+b(l-a) t^{2}\left[\sqrt{1+\left(\frac{\varepsilon_{d}}{t}\right)^{2}}-1\right] \frac{E_{0}}{\lambda}\left(e^{\lambda h / 2}-1\right)$.

From (23), (24), (33), (35), (38), and (39), we derived

$G=2 t^{2}\left[1-\left(\sqrt{1+\left(\frac{\varepsilon_{c}}{t}\right)^{2}}\right)^{-1}\right] \frac{E_{0}}{\lambda}\left(e^{\lambda h_{2}}-1\right)+2 t^{2}\left[\left(\sqrt{1+\left(\frac{\varepsilon_{d}}{t}\right)^{2}}\right)^{-1}-1\right] \frac{E_{0}}{\lambda}\left(e^{\lambda h / 2}-1\right)$.

The fact that Eq. (40) is exact match of Eq. (37) verifies the nonlinear fracture analysis developed when the modulus of elasticity is distributed along the beam height according to Eq. (32).

The effects were evaluated of material properties and crack location on the nonlinear Mode II fracture behavior of the functionally graded beam. The crack location was characterized by $2 h_{2} / h$ ratio. The $J$-integral was calculated by Eq. (18) at different values of parameter $k$ [refer to Eq. (3)] and presented in nondimensional form as $J_{N}=J /\left(E_{0} b\right)$. The $J$-integral value was plotted against $E_{1} / E_{0}$ ratio as shown in Fig. 4 . The curves in Fig. 4 indicate that the $J$-integral value decreases with increasing of $E_{1} / E_{0}$. This finding was attributed to increase of the beam stiffness. It can be observed also that the $J$-integral value decreases with increasing of $k$ at $E_{1} / E_{0}<1$. Increase of $k$ leads to increase of the $J$-integral value at $E_{1} / E_{0}>1$ (Fig. 4). The influence of crack location along the beam height and the value of parameter $\lambda$ [refer to Eq. (32)] on the Mode II fracture behavior was investigated too. For this purpose, the $J$-integral value was plotted in nondimensional form against $2 h_{2} / h$ ratio at different values of $\lambda$ as illustrated in Fig. 5. One can observe that the $J$-integral value decreases with increasing of $2 h_{2} / h$ ratio (this was explained with increase of the internal crack arm stiffness). The curves in Fig. 5 indicate also that the $J$-integral value decreases with increasing of $\lambda$ [this is due to increase of the exponent in Eq. (32), since $z_{1}$ varies in the interval $\left.-h / 2 \leq z_{1} \leq 0\right]$. 


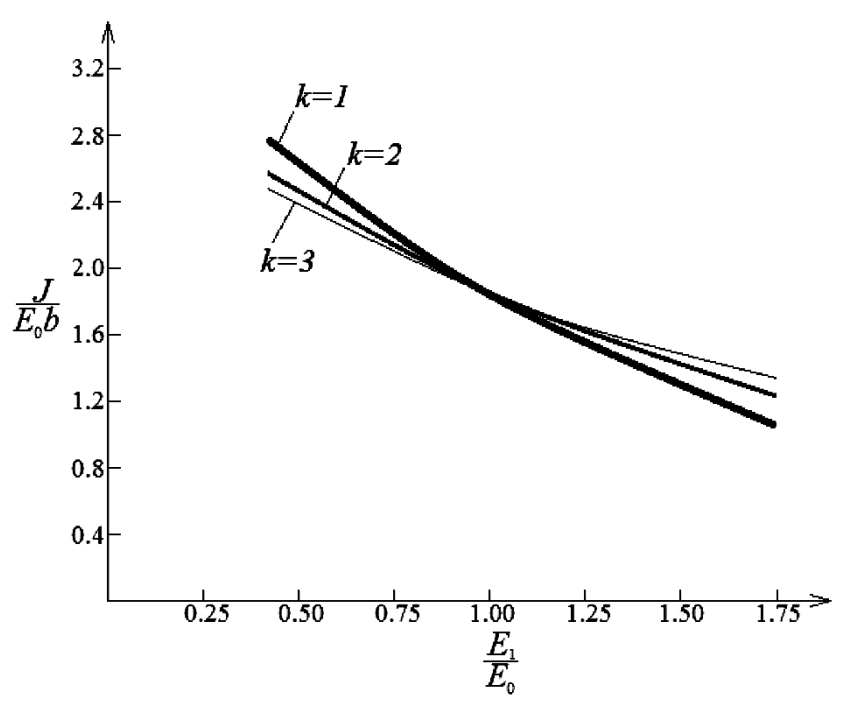

Fig. 4. The $J$-integral value in nondimensional form plotted against $E_{1} / E_{0}$ ratio at different $k$.

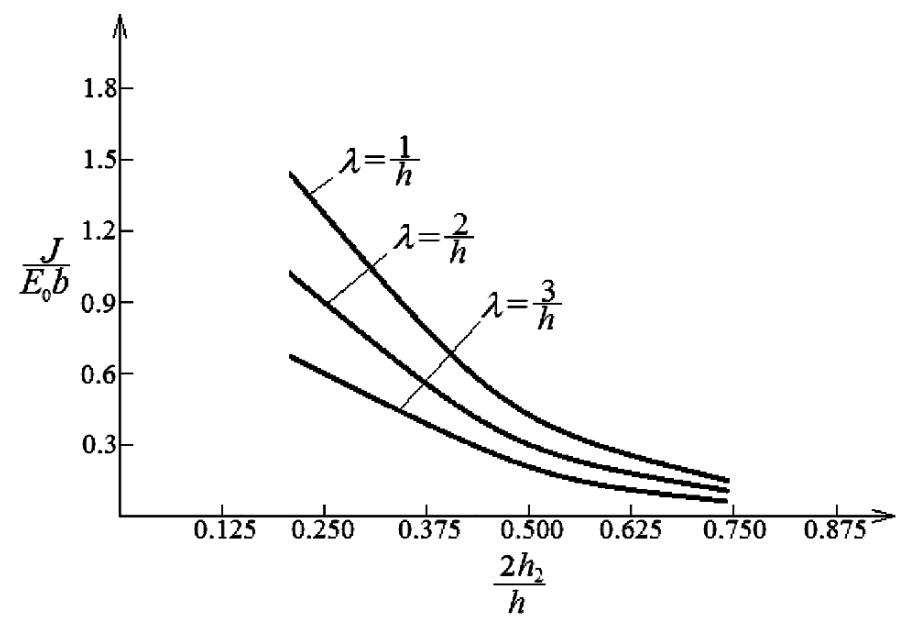

Fig. 5. The $J$-integral value in nondimensional form plotted against $2 h_{2} / h$ ratio at different $\lambda$.

Conclusions. Mode II longitudinal fracture in functionally graded beams was studied theoretically. For this purpose, a beam configuration containing two longitudinal cracks located symmetrically with respect to the centroid was suggested. In order to generate Mode II crack loading conditions, the internal crack arm was loaded centrically by a tensile force. The beam mechanical behavior was described by a nonlinear stress-strain relation. The fracture behavior was analyzed by the $J$-integral approach. The nonlinear solution derived was verified by developing an analysis of the strain energy release rate with considering the material nonlinearity. Two laws for variation of modulus of elasticity along the beam height were used. The influence of material properties and crack location on the nonlinear Mode II fracture was investigated. The results obtained can be applied for optimization of the functionally graded beam structure with respect to the Mode II fracture performance. The closed form analytical solutions derived are very useful for parametric investigations of nonlinear fracture. The present study contributes towards the understanding of fracture in functionally graded beams with nonlinear material behavior. 
Acknowledgments. The present study was supported financially by the Research and Design Centre (CNIP) of the UACEG, Sofia (Contract BN - 189/2016).

\section{Резюме}

Теоретично вивчено руйнування функціонально-градієнтних балок по моді II. Запропоновано конфігурацію балки з двома симетричними поздовжніми тріщинами для умов навантаження по моді II. Механічну поведінку балки описано за допомогою нелінійного співвідношення між напруженням і деформацією. Процес руйнування проаналізовано на основі використання $J$-інтеграла. Отримано аналітичний розв'язок на основі $J$-інтеграла для двох законів зміни модуля пружності по висоті балки. Виконано нелінійний аналіз швидкості звільнення енергії деформації з урахуванням балансу енергії для перевірки розв'язків на основі $J$-інтеграла. Отримані результати можуть бути використані для оптимізації функціонально-градієнтної структури балки при руйнуванні по моді II. Аналітичні розв'язки зручні для параметричного вивчення нелінійного руйнування функціонально-градієнтних балок, що дає підстави для подальшого розвитку нелінійної механіки руйнування функціонально-градієнтних матеріалів.

1. M. Niino, T. Hirai, and R. Watanabe, "The functionally gradient materials," J. Jpn. Soc. Compos. Mater., 13, 241-257 (1987).

2. M. Koizumi, "Functionally gradient materials the concept of FGM," Ceram. Trans., 34, 3-10 (1993).

3. S. Suresh and A. Mortensen, Fundamentals of Functionally Graded Materials: Processing and Thermomechanical Behavior of Graded Metals and Metal-Ceramic Composites, IOM Communications Ltd, London (1998).

4. T. Hirai and L. Chen, "Recent and prospective development of functionally graded materials in Japan," Mater. Sci. Forum, 308-311, 509-514 (1999).

5. M. M. Gasik, "Functionally graded materials: bulk processing techniques," Int. J. Mater. Prod. Tec., 39, 20-29 (2010).

6. M. M. Nemat-Alla, M. H. Ata, M. R. Bayoumi, and W. Khair-Eldeen, "Powder metallurgical fabrication and microstructural investigations of aluminum/steel functionally graded material," Mater. Sci. Appl., 2, 1708-1718 (2011).

7. A. Neubrand and J. Röde, "Gradient materials: An overview of a novel concept," $Z$. Metallkd., 88, 358-371 (1997).

8. S. K. Bohidar, R. Sharma, and P. R. Mishra, "Functionally graded materials: a critical review," Int. J. Res., 1, 289-301 (2014).

9. A. Mortensen and S. Suresh, "Functionally graded metals and metal-ceramic composites. 1. Processing," Int. Mater. Rev., 40, 239-265 (1995).

10. H. S. Shen, "Bending, buckling and vibration of functionally graded composite material plates and shells," Adv. Mech., 34, 53-60 (2004).

11. A. Szekrenyes, "Fracture analysis in the modified split-cantilever beam using the classical theories of strength of materials," J. Phys. Conf. Ser., 240, No. 1, 012030 (2010).

12. A. Szekrenyes and W. M. Vicente, "Interlaminar fracture analysis in the $\mathrm{G}_{\mathrm{II}}-\mathrm{G}_{\mathrm{III}}$ plane using prestressed transparent composite beams," Composites: Part A, 43, No. 1, 95-103 (2012).

13. F. Erdogan, "Fracture mechanics of functionally graded materials," Compos. Eng., 5, 753-770 (1995). 
14. G. H. Paulino, "Fracture in functionally graded materials," Eng. Fract. Mech., 69, 1519-1520 (2002).

15. P. Gu and R. J, Asaro, "Cracks in functionally graded materials," Int. J. Solids Struct., 34, 1-17 (1997).

16. M. T. Tilbrook, R. J. Moon, and M. Hoffman, "Crack propagation in graded composites,” Compos. Sci. Technol., 65, 201-220 (2005).

17. A. Carpinteri and N. Pugno, "Cracks in re-entrant corners in functionally graded materials,” Eng. Fract. Mech., 73, 1279-1291 (2006).

18. A. K. Upadhyay and K. R. Y. Simha, "Equivalent homogeneous variable depth beams for cracked FGM beams; compliance approach," Int. J. Fracture, 144, 209-213 (2007).

19. G. Anlas, M. H. Santare, and J. Lambros, "Numerical calculation of stress intensity factors in functionally graded materials," Int. J. Fracture, 104, 131-143 (2000).

20. V. V. Petrov, Nonlinear Incremental Structural Mechanics [in Russian], Infra-Ingeneria, Moscow (2014).

21. J. Lubliner, Plasticity Theory, Revised edn, University of California, Berkeley, CA (2006). 